\title{
Effect of autumn regrowth interval and nitrogen fertiliser on dry matter yield and plant characteristics of six forage species
}

K.E. MARTIN, R.H. BRYANT, S. HODGE and G.R. EDWARDS Faculty of Agriculture and Life Sciences, PO Box 85084, Lincoln University. Lincoln 7647, Christchurch, New Zealand kirsty.martin@lincolnuni.ac.nz

\section{Abstract}

Cold temperatures and drainage increase nitrogen $(\mathrm{N})$ losses from livestock production systems, so autum management and forage type were investigated as strategies to mitigate $\mathrm{N}$ loss whilst meeting animal requirements. The effect of regrowth interval and fertiliser rate on plant dry matter (DM) yield, plant $\mathrm{N}$ and digestible organic matter in the DM (DOMD) was measured in six forage species over 4 weeks regrowth, in Canterbury in autumn 2015. As regrowth interval increased, herbage DM yield increased (from $180 \mathrm{~kg}$ $\mathrm{DM} / \mathrm{ha}$ to $922 \mathrm{~kg} \mathrm{DM} / \mathrm{ha}, \mathrm{P}<0.05$ ) and $\mathrm{N}$ response rates were highest in perennial ryegrass and plantain $(\mathrm{P}<0.05)$. Herbage N\% in autumn was high at $>3.2 \%$ of DM and, in grasses and herbs, was positively associated with $\mathrm{N}$ application rate but negatively associated with regrowth interval $(\mathrm{P}<0.001)$. Delayed grazing by up to 4 weeks, under a moderate $\mathrm{N}$ regime, improved herbage quality and reduced herbage $\mathrm{N} \%$ in autumn. These results suggest plantain is a suitable alternative to perennial ryegrass to reduce $\mathrm{N}$ losses without impeding farm production in autumn

Keywords: chicory, plantain, perennial ryegrass, cocksfoot, white clover, red clover, nitrate leaching, nitrogen response rate

\section{Introduction}

Reducing nitrate leaching from agricultural land is an important goal for New Zealand farmers to ensure they are within environmental regulations developed by Regional Councils across New Zealand (Ministry fo the Environment 2014). These regulations will require large reductions in nitrogen $(\mathrm{N})$ inputs and outputs which may affect profitability.

Nitrogen fertilisers are often used in farm systems to maintain annual herbage production, however, their excessive use is discouraged due to the impact on $\mathrm{N}$ loss. Martin et al. (2017) compared the effect of $\mathrm{N}$ fertiliser on dry matter (DM) yield and $\mathrm{N}$ content (N\%) in a suite of forages at a set regrowth interval, and found interactions between species and $\mathrm{N}$ fertiliser rate. The results suggested different species may benefit from different management strategies to achieve animal production targets under a regulated $\mathrm{N}$ loss regime.
Nitrate leaching in pasture-based dairy systems ccurs largely from urine patches due to large quantities of mineral $\mathrm{N}$ deposited (Di \& Cameron 2002). The risk of leaching is greatest in the autumn when cooler temperatures reduce plant $\mathrm{N}$ uptake and higher rainfall increases drainage of soil mineral N. Plant characteristics, such as annual growth and winter activity, have been identified to improve capture of soil $\mathrm{N}$ (Malcolm et al. 2014, Woods et a 2016) as well as low herbage N\% . plat ald parn management practises; Bryant et al. (2012) showed interactions between regrowth stage and $\mathrm{N}$ fertilise on herbage $\mathrm{N} \%$. However, the study was restricted to perennial ryegrass and found that herbage quality declined during regrowth, reducing milk yield (Bryant et al. 2014). As little information exists on the effect of regrowth on alternate forage plant chacteristics, secies such as plant che grasses, may present an opportunity to reduce $\mathrm{N}$ losse without impeding quality. Therefore, the objective of the study was to compare the response of different forage species to $\mathrm{N}$ fertiliser rate and regrowth interval with respect to their forage characteristics which mitigate $\mathrm{N}$ loss and maintain farm production goals.

\section{Methods}

\section{Experimental site and design}

The current study was conducted 12 months after establishment between 10 March and 7 April 2015. The experiment was a split-split-plot design with three blocks situated under irrigation on a free-draining Templeton fine sandy loam (Immature Pallic soil, Hewitt 2010) at the Lincoln University Research Dairy Farm, Canterbury,

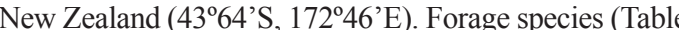
1) were the main plot treatments (area $=37.8 \mathrm{~m}^{2}$ ), N (the plit-split plot treatment $\left(\right.$ area $\left.=0.6 \mathrm{~m}^{2}\right)$. The $\mathrm{N}$ fertilise ates were 0,180 and $450 \mathrm{~kg} \mathrm{~N} / \mathrm{ha} / \mathrm{year}$ for grasses an herbs and 0,156 and $389 \mathrm{~kg} \mathrm{~N} /$ ha/year for legumes.

Establishment and management

This study was part of a larger field experiment examining the role of $\mathrm{N}$ in alternative forages to 
reduce nitrate leaching. Details of establishment and management are described in (Martin et al. 2017). Briefly, the experimental area was established in March commenced in spring 2014 using only mower harvests thus avoiding trampling and nutrient recycling of livestock. During the next 7 months harvest intervals in spring and summer for grasses and herbs were 32 and 26 days, respectively, and 41 and 35 days, respectively, for legumes to allow sufficient regrowth (Donaghy \& Fulkerson 1998; Moot et al. 2003; Lee et al. 2015). N fertiliser was applied following each harvest as calcium ammonium nitrate $(27: 0: 0: 0 ; \mathrm{N}: \mathrm{P}: \mathrm{K}: \mathrm{S})$, with the total annual $\mathrm{N}$ application rate split evenly throughou the year. Climate data was collected from Broadfields Meteorological Station, $1 \mathrm{~km}$ from the experimental area. Annual irrigation was $550 \mathrm{~mm}$, applied between

\section{Herbage measurements}

Regrowth data was collected weekly between 17 March and 7 April 2015. Herbage yield, botanical composition and plant characteristics were determined by harvesting three quadrats $(32 \times 60 \mathrm{~cm})$ per plot using hand shears, with an attachment set to $4 \mathrm{~cm}$ height to mimic grazing height. Harvesting occurred between 10:00 am and 12:00 pm and previously harvested area were avoided. Herbage was kept in the shade, before being transported to the laboratory once all plots had ${ }^{\circ} \mathrm{C}$ for 48 hours and weighed to determine herbage yield. The third quadrat was mixed and a sub-sample was frozen and freeze-dried for chemical analysis. Near-infrared spectrophotometry (NIRS, NIRSystem 5000, Foss, Maryland, USA) was used to determine plant characteristics, based on calibrations derived on quality was measured as DOMD (digestible organic matter in dry matter) and $\mathrm{N}$ was measured as a $\%$ of DM. Any samples outside the calibration spectrum were analysed by wet chemistry using the same methods a

Table 1 Forage species sown and their functional group, scientific name, cultivar and sowing rate (kg/ha).

\begin{tabular}{llllc}
\hline Forage & Functional group & Scientific name & Cultivar & Sowing rate $(\mathbf{k g} / \mathbf{h a})$ \\
\hline Perennial ryegrass & Grass & Lolium perenne & One 50 AR37 & 20 \\
Cocksfoot & Grass & Dactylis glomerata & Savvy & 8 \\
Chicory & Herb & Cichorium intybus & Choice & 8 \\
Plantain & Herb & Plantago lanceolata & Tonic & 10 \\
White clover & Legume & Trifolium repens & Kopu II & 5 \\
Red clover & Legume & Trifolium pratense & Sensation & 10 \\
\hline
\end{tabular}
April, this was $24.7 \mathrm{~mm}$ below the long-term average for (1981-2010). Soil temperature

\section{Herbage DM yield}

An interaction between $\mathrm{N}$ rate and regrowth interval $(\mathrm{P}<0.001)$ showed more rapid $\mathrm{DM}$ accumulation in high compared with nil $\mathrm{N}$ fertiliser treatments. Generally, there was a positive effect of both regrowth and $\mathrm{N}$ fertiliser rate on DM yield (Figure 1; Table 2). An interaction $(\mathrm{P}<0.001)$ between $\mathrm{N}$ fertiliser rate and species showed a positive response to $\mathrm{N}$ from herbs and grasses but no yield response to $\mathrm{N}$ fertiliser from legumes. Interaction between plant species and egrath $\mathrm{interval} \mathrm{showed} \mathrm{hat} \mathrm{the} \mathrm{pere}$ late differeses between species at begining of the regrowth interval, however by the befining of the all all species were similar in DM yield apart from plantain (Figure 1; Table 2; $\mathrm{P}=0.013$ ). Response to $\mathrm{N}$ fertiliser was highest $(\mathrm{P}<0.05)$ in plantain and perennial ryegrass $(23 \mathrm{~kg} \mathrm{DM} / \mathrm{kg} \mathrm{N})$ compared with chicory and cocksfoot (11 kg DM/kg N).

\section{Nutrient concentration}

The herbage N\% of all treatments (sampled above $4 \mathrm{~cm}$ ) was high, exceeding $3 \%$ of herbage DM. An interaction between $\mathrm{N}$ fertiliser and species revealed there was a positive relationship between $\mathrm{N}$ fertiliser Legume 2014 following cultivation. Control of herbage mas October and March. cen lavested. Two quadrats we oven-died at 60 experimental herbages (Martin et al. 2017). Herbage quality was meaned as DOMD (digestible orge Martin et al. (2017).

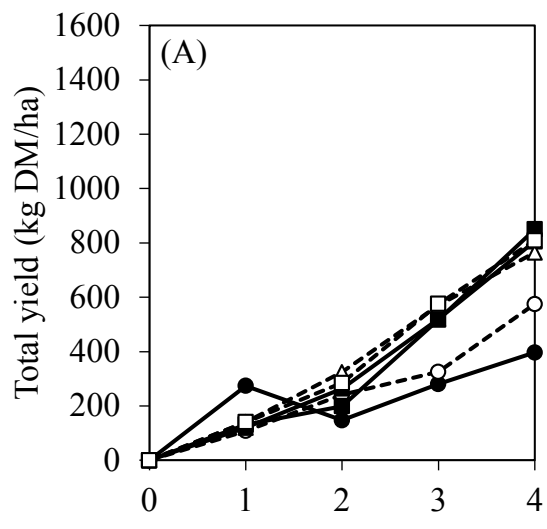

Regrowth cut (weeks)

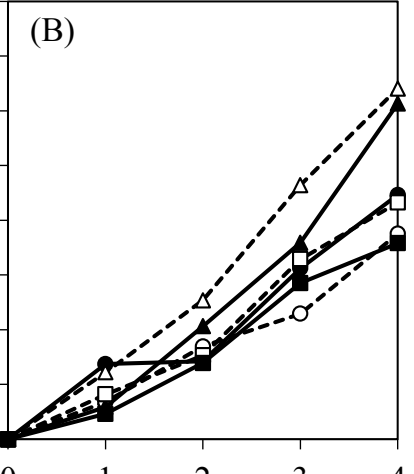

Regrowth cut (weeks)

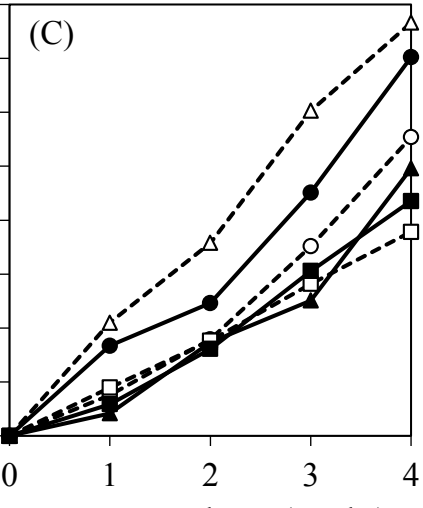

Regrowth cut (weeks)
Red clover

Figure 1 Effect of regrowth interval on herbage DM accumulation at three $\mathrm{N}$ fertiliser rates; six forage species: Perennial ryegrass $(-\bullet-)$, cocksfoot (-

Table 2 Average DM yield, plant N\% and DOMD of six forage species at three $\mathrm{N}$ fertiliser rates over 4 weeks. $\mathrm{LSD}_{0.5}=$ least significant difference at the $5 \%$ level. Means followed by different letters denote the values are significantly different at significant differ
the $5 \%$ level.

\begin{tabular}{|c|c|c|c|c|c|c|c|}
\hline & & \multicolumn{2}{|c|}{$\begin{array}{c}\text { Yield } \\
\text { (kg DM/ha) }\end{array}$} & \multicolumn{2}{|c|}{$\begin{array}{c}\mathrm{N} \% \\
\text { (\% of DM) }\end{array}$} & \multicolumn{2}{|c|}{$\begin{array}{c}\text { DOMD } \\
\text { (MJ/kg DM) }\end{array}$} \\
\hline \multirow[t]{6}{*}{ Species } & Chicory & \multicolumn{2}{|c|}{$509^{a}$} & \multicolumn{2}{|c|}{$4.0^{\circ}$} & \multicolumn{2}{|c|}{$77.5^{\circ}$} \\
\hline & Cocksfoot & \multicolumn{2}{|c|}{$438^{\mathrm{a}}$} & \multicolumn{2}{|c|}{$4.0^{\circ}$} & \multicolumn{2}{|c|}{$70.3^{\mathrm{a}}$} \\
\hline & Plantain & \multicolumn{2}{|c|}{$710^{\mathrm{b}}$} & \multicolumn{2}{|c|}{$3.5^{\mathrm{b}}$} & \multicolumn{2}{|c|}{$71.3^{\mathrm{ab}}$} \\
\hline & Red clover & \multicolumn{2}{|c|}{$440^{\mathrm{a}}$} & \multicolumn{2}{|c|}{$4.8^{\mathrm{d}}$} & \multicolumn{2}{|c|}{$71.3^{\mathrm{ab}}$} \\
\hline & Perennial ryegrass & \multicolumn{2}{|c|}{$526^{\mathrm{a}}$} & \multicolumn{2}{|c|}{$3.2^{\mathrm{a}}$} & \multicolumn{2}{|c|}{$73.1^{\mathrm{b}}$} \\
\hline & White clover & \multicolumn{2}{|c|}{$471^{a}$} & \multicolumn{2}{|c|}{$4.8^{\mathrm{d}}$} & \multicolumn{2}{|c|}{$80.0^{\mathrm{d}}$} \\
\hline Regrowth & 1 & \multicolumn{2}{|c|}{$180^{\mathrm{a}}$} & \multicolumn{2}{|c|}{$4.1^{\mathrm{b}}$} & \multicolumn{2}{|c|}{$70.6^{\mathrm{a}}$} \\
\hline interval & 2 & \multicolumn{2}{|c|}{$343^{b}$} & \multicolumn{2}{|c|}{$4.3^{\mathrm{c}}$} & \multicolumn{2}{|c|}{$73.8^{\mathrm{b}}$} \\
\hline \multirow[t]{2}{*}{ (weeks) } & 3 & \multicolumn{2}{|c|}{$624^{\circ}$} & \multicolumn{2}{|c|}{$4.1^{\mathrm{b}}$} & \multicolumn{2}{|c|}{$75.0^{\circ}$} \\
\hline & 4 & \multicolumn{2}{|c|}{$922^{\mathrm{d}}$} & \multicolumn{2}{|c|}{$3.8^{\mathrm{a}}$} & & \\
\hline $\mathrm{N}$ & Nil & & & & & & \\
\hline fertiliser & Medium & & & & & & \\
\hline rate & High & & & & & & \\
\hline & & $P$ value & $\operatorname{LSD}_{0.05}$ & $P$ value & $\operatorname{LSD}_{0.05}$ & $P$ value & $\operatorname{LSD}_{0.05}$ \\
\hline Species & & ** & 98.3 & ** & 0.158 & ** & 1.755 \\
\hline $\mathrm{N}$ fertiliser rate & & ** & 58.4 & ** & 0.075 & ** & 0.874 \\
\hline Regrowth interva & & ** & 52.6 & ** & 0.121 & ** & 1.053 \\
\hline$S \times R$ & & * & 143.3 & * & 0.292 & ** & 2.745 \\
\hline $\mathrm{S} \times \mathrm{N}$ & & ** & 146.1 & ** & 0.208 & NS & 2.362 \\
\hline$R \times N$ & & ** & 96.8 & * & 0.194 & NS & 1.785 \\
\hline$S \times N \times R$ & & NS & 239.6 & NS & 0.486 & NS & 4.487 \\
\hline
\end{tabular}

DOMD, digestible organic matter digestibility; $S$, species; $R$, regrowth interval; $N, N$ fertiliser rate; and $N S$, not significant. ** $P<0.001$; * $P<0.01$. 


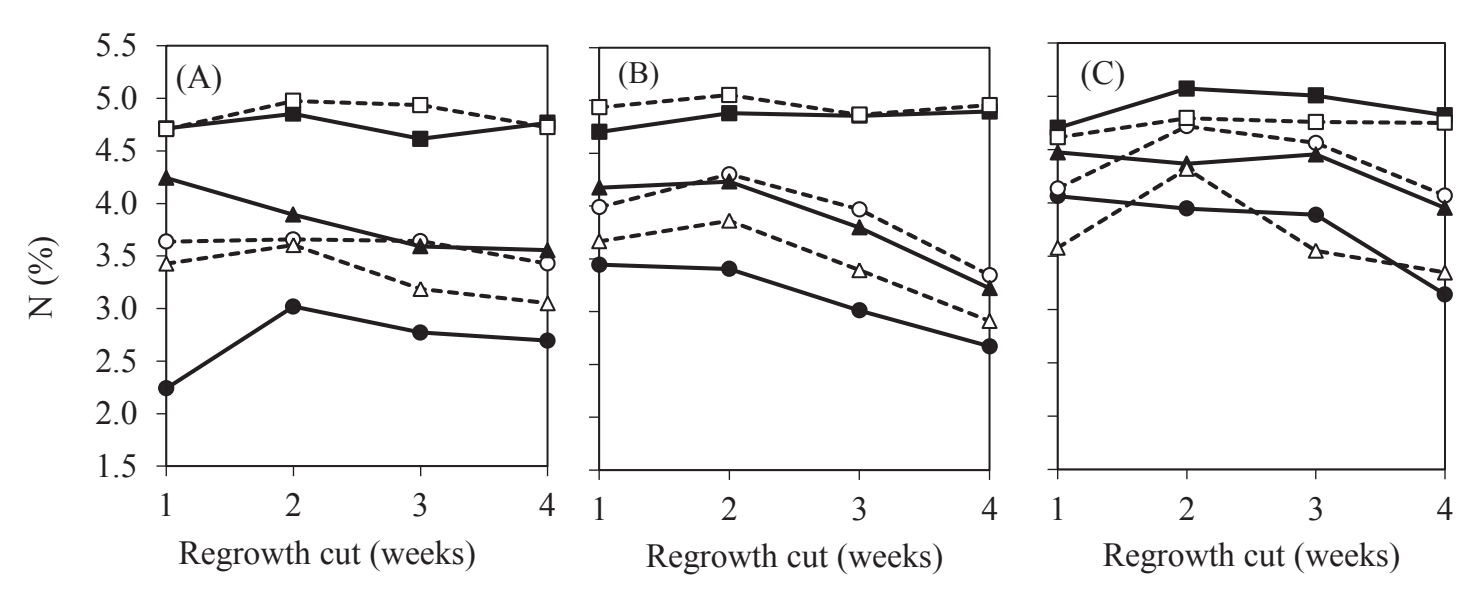

Figure 2 Effect of regrowth interval on plant $\mathrm{N} \%$ at three $\mathrm{N}$ fertiliser rates; nil (A), medium (B) and high (C), for six forage species: Perennial ryegrass $(-\bullet-)$, cocksfoot $(--\bigcirc--)$, chicory $(-\mathbf{\Delta}-)$, plantain $(--\Delta--)$, red clover $(-\square-)$ and white
clover $(---\square--)$. Points are mean values.
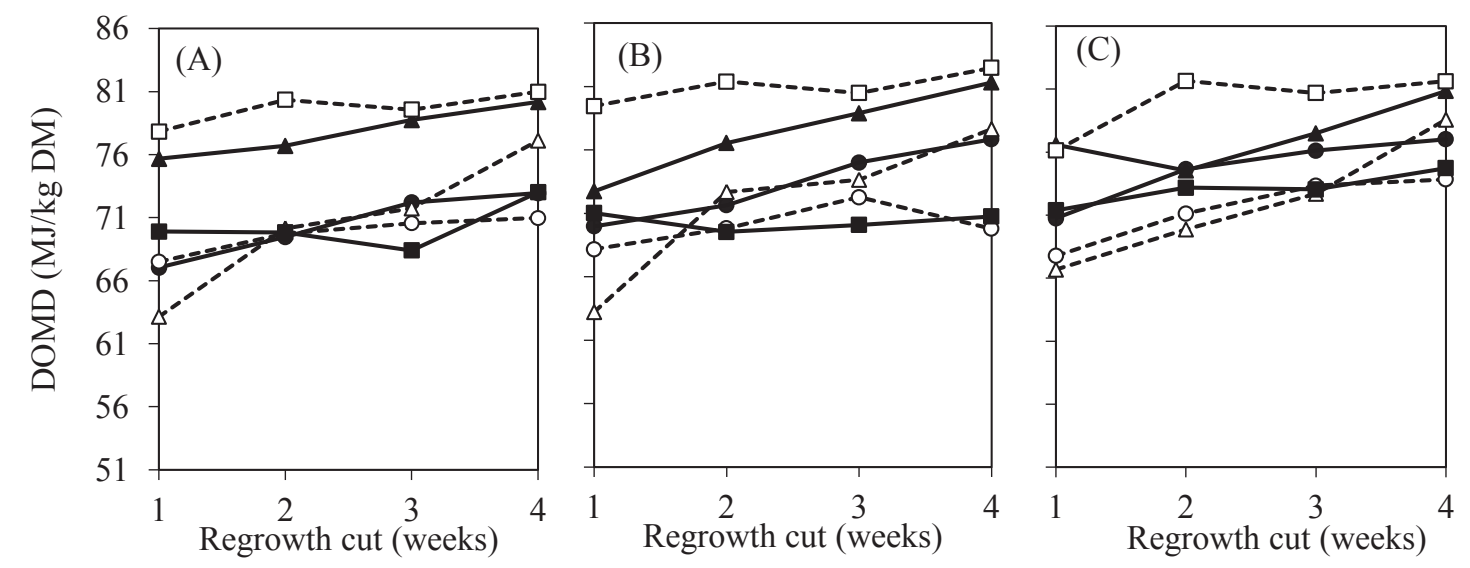

Figure 3 Effect of regrowth interval on DOMD at three $\mathrm{N}$ fertiliser rates; nil (A), medium (B) and high (C), for six forage species: Perennial ryegrass (- - ) cocksfoot $\left(---_{-}-\right)$, chicory $(-\Delta-)$, plantain $\left(--\Delta_{-}-\right)$, red clover (- $(-)$and white clover (- - - - -). Points are mean values.

rate and $\mathrm{N} \%$ for herbs and grasses, but no relationship for legumes which were always had high N\% (Table 2; Figure 2). Similarly, there were interactions between species and regrowth on herbage $\mathrm{N} \%$. Within legumes, $\mathrm{N} \%$ did not change with regrowth interval. In contrast, for both herbs and grasses the relationship between $\mathrm{N} \%$ and regrowth was quadratic. During the first 2 weeks herbage $\mathrm{N} \%$ increased then dropped by week 4 (Figure 2; Table 2; $\mathrm{P}=0.005$ ).

An interaction $(\mathrm{P}<0.001)$ between regrowth interval and species showed that there was no change in DOMD of red clover, while for other species, DOMD increased from week one to four (Figure 3). Differences between $\mathrm{N}$ fertiliser rates found DOMD were significantly higher $(\mathrm{P}<0.001)$ at the high $\mathrm{N}$ fertiliser rates, compared to the nil $\mathrm{N}$ fertiliser rates (Figure 3).

\section{Discussion}

\section{Herbage DM yield}

It was found that highest DM yield was achieved when $\mathrm{N}$ fertiliser was used on plantain and chicory at the longest regrowth interval. These findings are similar to previous studies (Minneé et al. 2013; Martin et al. 2017). On the other hand, under nil fertiliser, DM yield was greatest for legumes, so species re-ranked when $\mathrm{N}$ was applied. The lack of $\mathrm{N}$ response from legumes was expected (McKenzie et al. 1999; Martin et al. 2017) due to their N-fixing ability whi Differences limiting growth. Differences in growth between species, as determined by DM yield with different $\mathrm{N}$ rates was probably due to differences in thermal requirements $\left({ }^{\circ} \mathrm{C}\right.$ days) and hormonal signalling altering aboveand below-ground partitioning of photosynthates in response to day-length and defoliation (Moot et al. 2003; Powell et al. 2007). The autumn $\mathrm{N}$ response results demonstrate that perennial ryegrass and plantain need less $\mathrm{N}$ to produce similar DM yields compared with cocksfoot or chicory (Moore et al. 1991; King et al. 2012).

\section{Nutrient concentration}

The second management concern was identifying strategies to reduce herbage $\mathrm{N}$ content, as this is positively associated with $\mathrm{N}$ intake and urine $\mathrm{N}$ loss (Moorby 2014). At the finat rege and (Moorby 2014). At the highest in legme species, infermet and chicory, and lowest in plantain and perennial ryegrass. However, herbage $\mathrm{N}$ contents of over $3 \% \mathrm{~N}$ (18\% crude protein), which exceed cow late lactation requirements for protein, reflects the risk of high urinary $\mathrm{N}$ losses, irrespective of species (Castillo 2001). These results show that $\mathrm{N} \%$ was lowest at the final harvest due to $\mathrm{N}$ dilution rates in the plant cells as DM increases (Blaser 1964; Peyraud \& Astigarraga 1998). Similarly, moderate $\mathrm{N}$ fertiliser rates resulted in lower $\mathrm{N} \%$ compared with the high $\mathrm{N}$ rate. Although nil $\mathrm{N}$ fertiliser had the lowest herbage $\mathrm{N}$ content, the compromise in yield is likely to offset herbage $\mathrm{N}$ reductions.

The energy value (DOMD) of the herbage did not decline over the regrowth interval in any of the species, and remained high. This result was not expected as it was thought DOMD would generally decline (Buxton 1996; Rawnsley et al. 2002). The reason for a high DOMD throughout the regrowth was probably due to the time of year and the proportion of leaf in the herbage sampled above $4 \mathrm{~cm}$. It is well documented, grasses harvested before the fourth leaf stage are higher in DOMD due to no leaf senescence (Donaghy \& Fulkerson 1998). Leaf appearance interval (time taken for one leaf to fully expand) is influenced predominantly by temperature (Silsbury 1970) and soil moisture availability (van Loo 1992). The current trial ran in autumn whe consequently, leaf appearance rate was slower. As a result, at week four, the grasses were at the third leaf stage and leaf senescence did not occur. These results demonstrate that delaying regrowth to 4 weeks in autumn as a management strategy to reduce $\mathrm{N}$ losses, does not affect herbage quality and therefore farm production goals.

\section{Conclusions}

Any farm decision to reduce $\mathrm{N}$ is likely to be based around whether that decision also meets socio-economic goals. As feed costs are a major component of the farm system, decisions leading to changes which reduce feed supply are likely to limit adoption. The results of this study indicate delaying grazing of grasses, herbs and legumes up to 4 weeks in autumn increases DM yield, reduces herbage $\mathrm{N}$ content without compromising digestibility. The strong response to $\mathrm{N}$ fertilise from plantain and perennial ryegrass suggests that a moderate $\mathrm{N}$ fertiliser regime would address economic and environmental goals. However, because there was little management factors could do to reduce $\mathrm{N}$ content below $3 \%$, future strategies to further mitigate $\mathrm{N}$ loss through $\mathrm{N}$ intake should consider low $\mathrm{N}$ supplements.

\section{ACKNOWLEDGEMENTS}

This research was undertaken as part of the Forage for Reduced Nitrate Leaching program, with principal funding form the New Zealand Ministry of Business, Innovation and Employment. The program is a partnership between DairyNZ, AgResearch and Landcare Research.

\section{REFERENCES}

Blaser, R.E. 1964. Symposium on forage utilization: effects of fertility levels and stage of maturity on forage nutritive value. 1. Journal of Animal Science 23: 246-253.

Bryant, R.H.; Dalley, D.E.; Gibbs, J.; Edwards, G.R. 2014. Effect of grazing management on herbage protein concentration, milk production and nitrogen excretion of dairy cows in mid-lactation. Grass and Forage Science 69: 644-654.

Bryant, R.H.; Gregorini, P.; Edwards, G.R. 2012 Effects of $\mathrm{N}$ fertilisation, leaf appearance and time of day $\mathrm{N}$ fractionation and chemical composition of Lolium perenne cultivars in spring. Animal Feed Science and Technology 173: 210-219.

Buxton, D.R. 1996. Quality-related characteristics of forages as influenced by plant environment and agronomic factors. Animal Feed Science and Technology 59: 37-49.

Castillo, A. 2001. Improving nitrogen utilisation in dairy cows. PhD thesis. University of Reading.

Di, H.J. Cameron, K.C. 2002. Nitrate leaching in temperate agroecosystems: sources, factors and mitigating strategies. Nutrient Cycling in Agroecosystems 64: 237-256.

Donaghy, D.; Fulkerson, W. 1998. Priority for allocation of water-soluble carbohydrate reserves during regrowth of Lolium perenne. Grass and Forage Science 53: 211-218.

Hewitt, A.E. 2010. New Zealand soil classification. Manaaki Whenua Press, Lincoln, New Zealand.

King, C.; McEniry, J.; Richardson, M.; O'Kiely, P. 2012. Yield and chemical composition of five common grassland species in response to nitrogen fertiliser application and phenological growth stage Acta Agriculturae Scandinavica, Section B-Soil \& Plant Science 62: 644-658. 
Lee, J.M.; Hemmingson, N.R.; Minneé, E.M.K ; Clark, C.E.F. 2015. Management strategies for chicory (Cichorium intybus) and plantain (Plantago lanceolata): impact on dry matter yield, nutritive characteristics and plant density. Crop and Pasture Science 66: 168-183.

Malcolm, B.J.; Cameron, K.C.; Di, H.J.; Edwards, G.R.; Moir, J.L. 2014. The effect of four different pasture species compositions on nitrate leaching losses under high N loading. Soil Use and Management 30:58-68. high $\mathrm{N}$; Chapman, D.; Moir, J.; Cameron, K. 2017. Herbage dry matter (DM) yield and nitrogen concentration of grass, legume and herb species grown at differen nitrogen fertiliser rates under irrigation Animal Production Science 57: 1283-1288. https://dio.org/ 10.1071/AN16455.

McKenzie, B.A.; Kemp, P.D.; Moot, D.J.; Matthew, C.; Lucas, R.J. 1999. Environmental effects on plant growth and development. pp. 29-44. In: New Zealand pasture and crop science. Eds. White, J.; Hodgson, J. Oxford University Press: Auckland, New Zealand.

Ministry for the Environment, 2014. National policy statement for freshwater management. In: ME 1244 Ed. Ministry for the Environment. Wellington.

Minneé, E.; Clark, C.; Clark, D. 2013. Herbage production from five grazeable forages. Proceedings of the New Zealand Grassland Association 75: 245250.

Moorby, J. 2014. Relationship between the composition of fresh grass-based diets and the excretion of dietary nitrogen from dairy cows. The Future of European Grasslands 50: 686-689.
Moore, K.; Moser, L.E.; Vogel, K.P.; Waller, S.S.; Johnson, B.; Pedersen, J.F. 1991. Describing and quantifying growth stages of perennial forage grasses. Agronomy Journal 83: 1073-1077.

Moot, D.J.; Brown, H.E.; Teixeira, E.I.; Pollock, K.M. 2003. Crop growth and development affect seasonal priorities for lucerne management Legumes for dryland pastures. Grassland Research and Practice Series 11: 18-19.

Peyraud, J.L. Astigarraga, L. 1998. Review of the effect of nitrogen fertilization on the chemical composition, intake, digestion and nutritive value of fresh herbage: consequences on animal nutrition and $\mathrm{N}$ balance. Animal Feed Science and Technology 72 : 235-259.

Powell, A.M.; Kemp, P.D.; Jaya, I.K.D.; Osborne, M.A. 2007. Establishment, growth and development of plantain and chicory under grazing. Proceedings of the New Zealand Grassland Association 69:41-45.

Rawnsley, R.P.; Donaghy, D.J.;

P.A. 2002. Changes in the physology a quality of cocksfoot (Dactylis glomerata L.) during regrowth. Grass and Forage Science 57: 203-211.

Silsbury, J. 1970. Leaf growth in pasture grasses. Tropical Grasslands 4: 17-36.

van Loo, E. 1992. Tillering, leaf expansion and growth of plants of two cultivars of perennial ryegrass grown using hydroponics at two water potentials. Annals of Botany 70: 511-518.

Woods, R.; Cameron, K.; Edwards, G.; Di, H.; Clough, T. 2016. Effects of forage type and gibberellic acid on nitrate leaching losses. Soil Use and Management 32: 565-572.

\section{Further field evaluation of the controlled release nitrogen fertiliser} Smartfert ${ }^{\circledR}$

D.C. EDMEADES and R.M. McBRIDE agKnowledge Ltd, PO Box 9147 Hamilton 3240, New Zealand

doug.edmeades@agknowledge.co.nz

\section{Abstract}

Five field trials were conducted over 2 years in which the effects of single applications of different rates of a controlled release nitrogen $(\mathrm{N})$ fertiliser, Smartfert, on pasture production and pasture $\mathrm{N}$ concentration were measured, relative to the same rates of SustaiN. The 2016 trials also compared multiple applications of SustaiN with a single application of Smartfert. Pasture responses to SustaiN relative to the control generally occurred within the first one to three harvests following application and then declined and became negative in the later harvests. The pasture responses to Smartfert developed more slowly and were greatest after the third harvest. In terms of total production significant $(\mathrm{P}<0.05)$ responses to Smartfert relative to the same rate of $\mathrm{N}$ applied as SustaiN occurred in three trials. SustaiN significantly increase pasture production at one site relative to Smartfert. In three trials pasture production from single applications of Smartfert applied at 100 $\mathrm{kgN} / \mathrm{h}$ a were the same and in one case better $(\mathrm{P}<0.05)$ than three consecutive applications of $33 \mathrm{~kg} \mathrm{~N} / \mathrm{ha}$ of SustaiN. The soluble N fertilisers, urea and SustaiN, elevated the mixed-pasture $\mathrm{N}$ concentration relative to control and to Smartfert in the first harvest following application. The nitrogen use efficiency (NUE, kg DM/ $\mathrm{kg}$ fertiliser $\mathrm{N}$ applied) of Smartfert was significantly greater $(\mathrm{P}<0.05)$ than for SustaiN in two trials.

Keywords: fertiliser, nitrogen, nitrogen use efficiency, pasture, Smartfert, urea, SustaiN

\section{Introduction}

New Zealand uses about 350000 tonnes of fertiliser N annually (Fertiliser Matters 2010) most of which is applied in a readily available, water-soluble form, such as urea, ammonium sulphate or diammonium phosphate. The $\mathrm{N}$ in such products is subject to losses to the environment via: volatilisation (ammonium), denitrification (nitrogen and nitrous oxides gases), leaching (nitrate) and runoff (ammonium and nitrate). leaching (nitrate) and runoff (ammonium and nitrate). There are international (Our Nutrient World 2013)
and national (Ministry of Primary Industries 2013) initiatives to increase nitrogen $(\mathrm{N})$ use efficiency (NUE), driven by both economic and environmental considerations and concerns. There are many ways to define and hence measure NUE and de Klein et al. (2016) have usefully defined three broad categories:
Crop NUE, Animal NUE and Whole farm NUE. They defined the Crop NUE as the crop dry matter (DM) per unit of $\mathrm{N}$ input of which fertiliser NUE $(\mathrm{kg} \mathrm{DM} / \mathrm{kg}$ fertiliser $\mathrm{N}$ applied) is a subset.

Edmeades (2015) reported on the evaluation of Smartfert, a controlled release nitrogen fertiliser which, in three field trials, increased the NUE $(\mathrm{kg} D M / \mathrm{kg} \mathrm{N}$ applied) in pastures by between $5-50 \%$, depending on the site and the rate of application.

In this paper the results from five further field trials are discussed focussing on the potential economic and environmental benefits and the NUE $(\mathrm{kg} \mathrm{DM} / \mathrm{kg}$ fertiliser $\mathrm{N}$ applied) of Smartfert.

\section{Methods}

\section{Field Trials}

作 been described earlier (Edmeades 2015). Mixedpasture samples were collected at each harvest from these trials, either on a per plot basis (Taupo) or bulked over replicates (Rotorua and Northland) and have been analysed for total nitrogen concentration ( $\mathrm{N} \%$ ). These results are reported in this paper.

Five further field trials were conducted, two in 2015 and further three in 2016. All these trials (mowing with clippings removed, plot size $2 \times 6 \mathrm{~m}$ ) were on clover-based pastures using standard management and measurements techniques (Lynch 1966). The trial designs and treatments, however, were changed between years driven largely by commercial rather than reated with a urease inhibitor), a proprietary product from Ballance AgriNutrients Ltd was used as the standard for comparison with Smartfert.

The two 2015 trials, one each in Northland and Rotorua, comprised six replicates of seven treatments: control, SustaiN $30 \mathrm{~kg}$ N/ha (SustaiN30), SustaiN (Smartfert30), Smartfert $60 \mathrm{~kg} \mathrm{~N} / \mathrm{ha} / \mathrm{yr}$ (Smartfert60) and a 50.50 mix of SustaiN and Smartfert applied at 30 or $60 \mathrm{~kg} \mathrm{~N} / \mathrm{ha}$. The treatments were applied once at 30 or $60 \mathrm{~kg} \mathrm{~N} / \mathrm{ha}$. The treatments were applied once at the commencement of the trials in September and the production measurements terminated after 6 harvests in either January or February. Pasture DM ( $\mathrm{kg} \mathrm{DM} / \mathrm{ha})$ was measured on a per plot basis, and for the Rotorua measured on samples bulked by treatments. scientific considerations. For example, SustaiN (ure $60 \mathrm{~kg} \mathrm{~N} / \mathrm{ha}$ (SustaiN60), Smartfert $30 \mathrm{~kg} \mathrm{~N} / \mathrm{ha}$ 